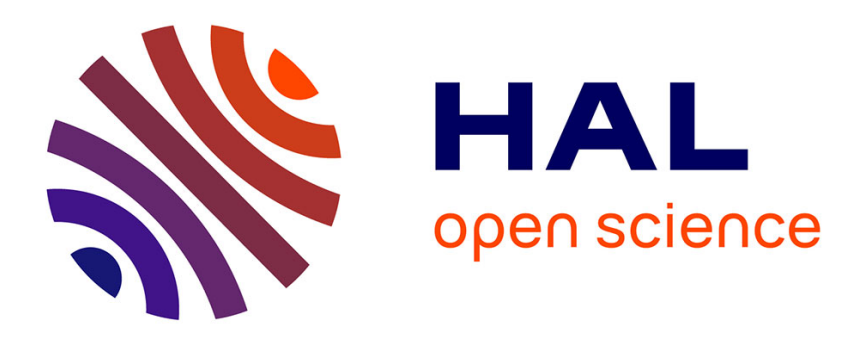

\title{
Language Inclusiveness in Education: Implications for Immigrant Students in France and New Zealand
}

Fiona Smythe

\section{To cite this version:}

Fiona Smythe. Language Inclusiveness in Education: Implications for Immigrant Students in France and New Zealand. New Zealand Journal of Educational Studies, 2020, 55, pp.215 - 246. 10.1007/s40841-020-00164-2 . hal-03224353

\section{HAL Id: hal-03224353 \\ https://hal.science/hal-03224353}

Submitted on 11 May 2021

HAL is a multi-disciplinary open access archive for the deposit and dissemination of scientific research documents, whether they are published or not. The documents may come from teaching and research institutions in France or abroad, or from public or private research centers.
L'archive ouverte pluridisciplinaire HAL, est destinée au dépôt et à la diffusion de documents scientifiques de niveau recherche, publiés ou non, émanant des établissements d'enseignement et de recherche français ou étrangers, des laboratoires publics ou privés. 


\section{New Zealand Journal of Educational Studies}

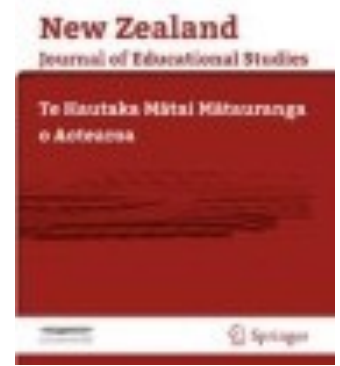

ISSN 0028-8276 Volume 55 Number 1

Journal homepage: https://www.nzare.org.nz/publications/

\section{Language inclusiveness in education: implications for immigrant students in France and New Zealand}

\section{Fiona Smythe}

To cite this article: Fiona Smythe (2020). Language inclusiveness in education: implications for immigrant students in France and New Zealand. New Zealand Journal of Educational Studies, 55, 215-246. DOI: 10.1007/s40841-020-00164-2

The final publication is available at: https://doi.org/10.1007/s40841-020-00164-2 


\title{
Language inclusiveness in education: implications for immigrant students in France and New Zealand
}

\author{
Fiona Smythe \\ Laboratoire Cultures-Éducation-Sociétés (LaCES), Université de Bordeaux, Bordeaux, France
}

Abstract:

Since 2016, educational environments all over the world are being precipitated towards change and adaptation, in response to mass global immigration and increasing numbers of newly-arrived plurilingual children in schools. France and New Zealand provide two examples of populations that are highly linguistically diverse, yet take differing approaches to the inclusion of immigrant languages in the educational environment. This article compares the effects of language policies in a francophone/anglophone context on the inclusion of plurilingual immigrant children in schools, on three tiers: the language of schooling (French/English), second language options in schools, and the treatment of immigrant languages. Two main questions are explored: (1) How inclusive are language education policies in France and New Zealand? (2) How are educational environments responding to greater numbers of newly-arrived plurilingual students in schools, as well as the demand for language inclusiveness from established immigrant communities? A number of similarities emerge (school systems essentially dominated by monolingualism in the language of schooling), as well as differences (visible trends towards language inclusiveness in policy and practice in 2020). Findings support the argument that plurilingual approaches to teaching and learning improve educational outcomes for immigrant students, and therefore that educational environments that cultivate "language inclusiveness", particularly during the newly-arrived phase, are better equipped to support learning for immigrant students in schools.

ARTICLE HISTORY

Received 11 Dec 2019

Accepted 3 April 2020

Published 16 April 2020

\section{KEYWORDS}

Education;

immigrant students;

language inclusiveness; plurilingualism

\section{INTRODUCTION}

France and New Zealand are both countries that are home to immigrant populations with highly diverse social and educational backgrounds, and this poses challenges for schools working with immigrant children. The inclusion of immigrant languages in education is one solution that is proposed by international bodies including the Council of Europe and European Commission, and supported by multiple international studies (for examples see Council of Europe's Languages in Education/Languages for Education project 2006). Recent international studies provide ongoing evidence across and within countries of the multiple benefits of plurilingual approaches for positive outcomes in education for immigrant children (see Beacco 2005 for an overview of international studies; Berry et al 2006; Zarate et al 2008), and are underpinned by findings over the past 40 years that unequivocally support the benefits of bilingualism for literacy and school achievement (Cummins 1979, 2001; Auger 2011; Bialystok 2011).

A contemporary umbrella term for educational approaches that recognise the benefits of plurilingualism, and in particular for immigrant children and their success in schooling, is "language inclusiveness". Language inclusiveness is an approach to languages in education that calls for space to be created for the languages of all participants within the educational environment. It forms part of an aspiration shared amongst teachers and educators for better educational outcomes for immigrant children, and advocates for innovative approaches in education that recognise the multiple benefits of both foreign language learning and the strengthening of first and heritage languages. In this article, I compare recent developments in educational policy and practice in France and New Zealand, looking at how each country is evolving since 2016 towards inclusion of languages within educational environments, in particular the inclusion of the languages of immigrant students in schools. 
I develop an argument for language inclusiveness and its potential to support and improve learning processes for refugee and immigrant children in France and New Zealand, around two student-centred statements, as follows:

1. Plurilingualism is a contemporary social reality, as schools are peopled by plurilingual and multicultural student populations; and therefore educational policy and practice that seeks to be responsive to student diversity must embrace the plurilingual reality of schools today.

2. From 2016, a new phase of educational evolution is being signalled in response to rising numbers of plurilingual children in schools, including refugee and migrant students who bring with them specific sets of educational needs and aspirations.

These two points place immigrant students and their languages at the centre of this comparative overview of how educational policy and practice is evolving towards language inclusiveness in France and New Zealand. I explore to what degree educational environments in France and NZ are responsive to plurilingualism as a contemporary social reality through the question: How inclusive are language education policies in France and NZ? I then highlight the potential evolution of education towards language inclusiveness in both countries through the question: How are educational environments responding to greater numbers of newlyarrived plurilingual students in schools, as well as the demand for language inclusiveness from established immigrant communities?

\section{THEORETICAL FRAMEWORK}

This article is drawn from research carried out between 2017-2019 in France and New Zealand, as part of $\mathrm{PhD}$ research comparing the educational experiences of immigrant teenagers in schools during the newlyarrived phase of language-of-schooling acquisition and integration into school systems dominated by French (in France) and English (in New Zealand), despite the linguistic diversity of student populations. The research examines the role of first languages during the newly-arrived learning phase for 13-15 year old immigrant students in two essentially monolingual educational contexts, however situated within the broader context of increasing sensitivity towards diversity and recognition of the multiple benefits of plurilingualism. While it is still too early to present data and findings from observations carried out with newly-arrived immigrant students in schools, this article presents an argument for language inclusiveness based on the well-supported premise that first languages play an essential role in acquisition of the language-of-schooling, and thereby in successful academic outcomes for immigrant students, through a broad overview of language education policy, languages in the curriculum, and attitudes towards plurilingualism and various immigrant communities in France and New Zealand.

Findings from research in language education consistently support the view that inclusion of pluralities of identities and languages, and those of cultural heritage in particular, creates a platform from which to improve learning, engagement, and construction of knowledge, with a view to academic success. Research into the cognitive functioning of plurilingual people has found that the ability to use more than one language tunes other cognitive functions in the brain, such as attentional control (Abutalebi, 2012; Cummins 1979, 2001). Other research shows that plurilingualism favours creativity, as it allows thoughts to be organised in a different way and offers alternative platforms from which to view the world (Berthoud, Grin \& Lüdi, 2013). An underlying concept of the creative effect of plurilingualism is that human activity is contextual and interactional, termed the "integrative model" of plurilingualism (Berry 1997; Jensen 2001). In the integrative model, language acquisition is more than skills-based, rather it is the development of a "repertoire in language competence", defined as an ensemble of verbal and non-verbal resources (Lüdi, 2019). Including this linguistic and cultural repertoire in the child's learning processes therefore opens up areas of cognitive functioning that potentially enhance learning. In contemporary France and New Zealand, the need to translate this theory into teaching practice is not only relevant but becoming an urgent social imperative, as societies today are complex interactive sites of linguistic, cultural and religious diversity.

The theoretical framework for the language inclusiveness argument is drawn from international research into bilingualism and language education since the 1970s, that strongly supports the learning of second languages via first language competence (Corson 2001; Cummins 1998, 2001). The view is that of bilingualism as additive and an advantage to learning processes, rather than as a deficit and obstacle to success in education - a view that is yet to be embraced in monolingual French/English educational policy 
and practice in the two countries compared (Auger 2011; May 2002). May (2002) highlights three key findings from the research on bilingualism as additive, that underpin a language inclusiveness argument:

(i) Bilingualism is an advantage in learning, rather than a deficit, as bilinguals have been shown to perform better than monolinguals in cognitive and academic tasks that are language-based, as well as demonstrating higher sensitivity to language-oriented social situations.

(ii)

Bilingual education programmes are more successful in helping students to acquire a second language. This is an additive view of bilingualism, as it supports the premise that learners are able to transfer their first language skills to processes involved in second language learning.

(iii) Language-of-schooling acquisition is least effective when first languages are excluded from students' learning processes. This argues for maintaining and developing first language skills in the EL/FLS classroom, as where the first language is proficient, second language proficiency develops in relation to this existing linguistic foundation.

This theoretical framework aligns with the Council of Europe's promotion of languages in education, supported by a collection of publications within the project Guide for the Development of Language Education Policies in Europe: From Linguistic Diversity to Plurilingual Education (2007). The project traces the development of language education policies through two main evolutionary phases in thinking on language education: from language teaching methodologies focused on communication and European mobility during the 1970s (Threshold Levels), to the promotion of a common European support for plurilingual and intercultural education since 2001 (Common European Framework of Reference for Languages 2001; European Languages Portfolio 2001). The current era of thinking promoted by the Council of Europe is therefore that of a shared educational framework for the promotion of language learning that recognises (1) the intrinsic value of plurilingualism for the individual and (2) the promotion of plurilingualism as an educational objective for European member states (Beacco 2005).

As the research is being carried out in schools in France and New Zealand, I am interested in both international and local research that concurs with the well-established view that bilingualism and/or plurilingualism advantage learning, and that first languages therefore occupy an essential place in effective learning for immigrant students. While New Zealand language education objectives are focused on bilingualism as revival and/or protection of linguistic heritage (NZ has a unique commitment to Māori language in education, and biculturalism under the Treaty of Waitangi), the European emphasis is on educating for plurilingual individuals and societies for a modern "Europe without borders" (the European commitment to proficiency in 3 languages, in accordance with the European Charter for Regional and Minority Languages 1992). There are therefore two sets of literature to examine - bilingualism and plurilingualism - which are not mutually exclusive but form part of a continuum of international research that intersects language education, policies of immigration / education / language, immigrant adaptation and acculturation, diversity and inclusion, and youth identity construction in multicultural contexts, to name a few. Here I focus on the inclusion of refugee and migrant languages in education policy and school curricula, within the multicultural yet relatively monolingual educational contexts of France and New Zealand.

\section{DEFINITIONS}

As such, this article draws on both francophone and anglophone literature, and the choice of terminology attempts to find common ground between shared concepts. The problematic of direct translation leading to terminology that does not sit comfortably in one language or the other is explained. Where there are differences in connotation, the rationale for a choice of term is also explained.

- "Language inclusiveness" is a term that attempts to encompass both French and English concepts of including the first languages of all immigrant students in their learning processes and experiences of education. More than this, "language inclusiveness" also characterises education projects that embrace the linguistic and cultural plurality that exists within schools. Language inclusiveness has a political connotation, in that it works in resistance to education systems which reproduce and reinforce inequality and exclusion, "par la manière dont ils fonctionnent, dont ils sélectionnent, évaluent, orientent les élèves, et aussi par les modalités pédagogiques qu'ils privilégient" [by the way in which education systems function, how they select, assess and guide students, and also through the pedagogical methods that systems favour.] (Coste, 2012). In practice, language inclusiveness can mean the exposure of all children 
to language diversity in the classroom and in the broader school context. In the French context, a paradigm of inclusion is framed by notions of social justice and equal opportunity (Dubet, 2010). The inclusion paradigm stems from a social model that refutes exclusion on the basis of difference, and seeks to re-position the traditional view of students "in school" by conceptualising students rather as "members of school" (Ebersold, 2019). The French term "inclusion" is therefore used to highlight cases where children risk marginalisation within the education system, and has recently undergone a conceptual shift to include immigrant children as well as children with special needs (Rigoni, 2019). "Une pédagogie d'inclusion", "intégration et inclusion scolaire", "l'inclusion des minorités en contexte scolaire", "classes d'inclusions" are terms that describe how schools are working in various ways to inclusively support migrant students in their schooling. In the anglophone literature, "inclusion" in education often refers to acceptance of gender, sexuality and individuality, rather than culture and language (ie, "the language of inclusion"). Terms such as "linguistically inclusive classrooms", "language inclusion/exclusion" and "inclusive language classrooms" are found in the anglophone literature, and refer more to teaching practice than to the child's agency in their own learning processes, or to a wider education project. I therefore use the term "language inclusiveness" as it straddles the political aspect of working against systemic inequality, the social principle of inclusion, language practices within schools, and the child's choice to use their first language as part of a repertoire of learning strategies. The term brings together the various concepts around inclusion of immigrant students in education, from both the francophone and anglophone literature.

- "Plurilingual" is a term central to concepts outlined in the work of the Council of Europe, that describes processes and objectives of education that integrate the teaching and learning of languages into general education. This principle of language integration gives rise to various formulations such as "éducation plurilingue et interculturelle", "enseignement plurilingue", "approche(s) plurielles(s) de l'apprentissage", and "competences plurilingues". As an approach to education that emphasises the advantages of integrating language learning in all subject areas, plurilingual education is "both the process and outcomes of education through languages":

“... connotée par les travaux du Conseil de l'Europe, "éducation plurilingue et interculturelle", présente l'avantage relatif de pouvoir recouvrir à la fois la finalité (éducation à) et la démarche (éducation par)." [contextualised by the work of the Council of Europe, "plurilingual and intercultural education presents the relative advantage of covering both the final outcomes of education (education towards) and the process (education via)] (Coste, 2012)

- "Plurilingualism" refers to the individual who has a capacity in two or more languages. As an education strategy, teaching and learning for plurilingualism was most recently defined by Daniel Coste (2019) as "the construction of learning via two or more languages - not simply the development of languages, but centralised on the construction of knowledge through language".

- "Immigrant student(s), élève(s) allophone(s)". The term "élèves allophones" has been current in French discourse since the Ministry of Education circular of 2012, and is defined as "(u)n élève allophone est un élève nouvellement arrivé en France et parlant une voire d'autres langues que le français" [an allophone student is a student newly-arrived in France who speaks one or more languages other than French]. In New Zealand, the term "migrant and refugee background students" is in current use in Ministry of Education documents, and distinguishes the longer-term integration objectives of these students from "international fee-paying students" who are studying in NZ on fixed period student visas. In this article, the term "immigrant students" is used as an umbrella term that comprises elements common to all of these various groups of students: the experience of being newly arrived in a country, speaking a language (or languages) other than the language of schooling, pertaining to an intercultural identity, and having integration or resettlement objectives in either the short or long-term. The definition remains focused on refugee and migrant students and their languages, as IFPs have a distinct set of (often short-term) educational goals around learning English and are therefore less implicated in the language inclusiveness argument.

\section{IMMIGRANT POPULATIONS in FRANCE and NEW ZEALAND}

National statistics on the number of plurilingual people among the populations of France and New Zealand reveal several interesting similarities and differences. Both countries are highly diverse linguistically, and at the same time demonstrate that choices about language learning in schools are to a large degree driven by national political trends and current political attitudes towards immigration, rather than by educational policies 
acting in the interests of our immigrant students and their success in education. While the French education system is pursuing English as a second language choice, almost to the exclusion of other languages, New Zealand has a relatively diverse range of second language choices in schools, and accords an important place to Te Reo Māori as a newly-mandated second language in primary schools, alongside a strong and established Māori immersion schooling movement from early childhood kohanga reo through to tertiary education.

\section{FRANCE}

\section{(a) Languages of France's immigrant population}

France's total population of 67.19 million in 2018, makes her the country with the second largest population in Europe, after Germany. $87.2 \%$ of the population speak French as their first language, with regional languages spoken by $18.9 \%$ of the population, alongside French (Insee 2018). According to the most recent Insee figures of $2018,8.9 \%$ of the French population (5.8 million people) are immigrants, and another $10 \%$ (6.8 million people) are second generation immigrants born in France. Among these two immigrant populations combined, the number of Arabic speakers is estimated at $60.2 \%$ of the total immigrant population, and speakers of African languages at $24.3 \%$ of the total immigrant population ${ }^{1}$ (Insee 2018). These combined figures represent a substantial knowledge capital present in the student and teaching corpus - a linguistic and cultural capital that is not ascribed value within the education system, in that Arabic and African languages are scarcely taught in French schools, and France's 26 regional languages remain segregated to bilingual schools within regions.

Languages spoken in France by number of speakers 2018

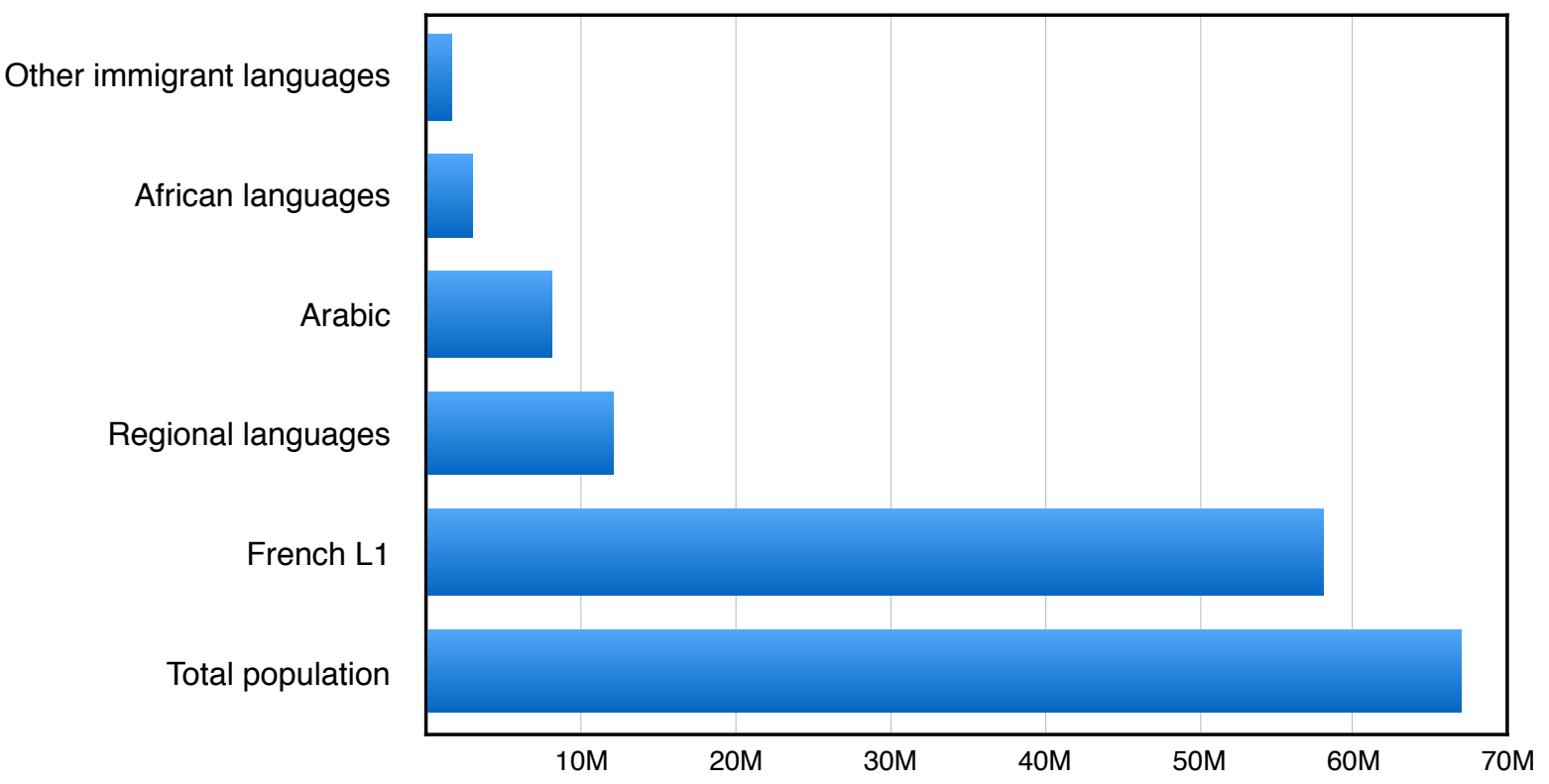

In addition to France's historical immigration trends that have remained stable since 1990 with an annual rise of $3-4 \%$, France has seen a sharp increase in immigration since 2010 , with an $8.17 \%$ increase in regular immigration between 2010-20152, and 122,743 applications for asylum received in 2018 compared to 57,337 applications in $2011^{3}$. Of the asylum applications made in France in 2018, more than 23,000 are children, signalling a significant increase in the number of newly-arrived immigrant children in the uncertain situation of awaiting refugee status, who will be enrolled in local French schools.

\footnotetext{
${ }^{1}$ Note: INSEE does not publish figures on languages spoken, but countries of origin give an indication of the languages spoken.

2 France Immigration Statistics 2019

${ }^{3}$ statista.com Accepted asylum applicants in France 2014-2019
} 
According to latest available Ministère de l'Éducation Nationale figures, there were 64,350 immigrant students in French schools between 2017-2018. Of these, the majority are students in primary schools $(30,385), 27,110$ students are in collège, and 6,855 students are in high school ${ }^{4}$. These students are made up of both newly arrived immigrant students during the 2017-2018 academic school year, and immigrant students (that is, of nationalities other than French) who were already in school at the time of the survey. Immigrant students comprise $0.56 \%$ of the total student population in France, a small figure that does not fully reflect the plurilingual character of the student body, as several groups of plurilingual children are not included in these figures - for example, second generation children of immigrant parents, bilingual children of mixed marriages, French children who speak a regional language in addition to French, and French children who have returned to schooling in France after a period of education overseas. If these children are also included, the number of plurilingual children in French schools rises significantly. As example, it is estimated that $59 \%$ of second generation immigrant children inherit the language of origin of their parents if one parent is an immigrant, and $90 \%$ if both parents are immigrants. The linguistic heritage is transmitted to a third generation of children in France, as an estimated $37 \%$ of these second generation plurilingual children pass on the language to their own children (Insee, 2015).

\section{(c) 2nd language options in French schools}

English is the dominant choice of second language taught in French schools, beginning in pre-school and continuing through to high school. During the first years of primary schooling, alongside English at $79.6 \%$, other foreign languages are represented in small numbers - German $15.1 \%$, Spanish $2.4 \%$, Italian $1 \%$, Portuguese and Arabic both at $0.2 \%$, with other romance languages at $3.6 \%$ combined. However by the end of high school, English occupies $91 \%$ of the entire foreign languages options in Years 11-12 at public high schools, while Arabic is no longer taught from Year 7 (RERS, 2012). A language inclusiveness view questions this preference for English as a second language from a young age, suggesting that "parents are managing the future of their child from a young age. It would be better to think about how to effectively equip the child linguistically, through languages other than English. A child who learns another foreign language early (for example Russian or German), will more easily learn English as a 3rd language in collège." (Dalgalian, 2019). The underlying principle is that language learning is cognitively and socially accumulative - the benefits of beginning language learning young will facilitate plurilingual capacities in the older child, as evidenced by language programmes in other European countries such as Switzerland and Finland. So we see currently a form of "dual monolingual" approach to languages in the French education system (Forsdick 2007), where French is almost exclusively the language of schooling, with English dominating as the second language choice from the first years of schooling.

\section{NEW ZEALAND}

\section{(a) Languages of New Zealand's immigrant population}

New Zealand's comparatively small population of 4.7 million is also highly ethnically and linguistically diverse, however with smaller numbers of immigrants speaking a wider range of world languages. The dominant population is of European descent $(70.2 \%), 16.5 \%$ are indigenous Māori, $15.1 \%$ identified with at least one Asian ethnicity, and $8.1 \%$ are Pasifika (of whom almost two-thirds were born in NZ). New Zealand has also seen an increase in immigration in the past decade, with a $72 \%$ increase in migrant arrivals between 2010-20175. Protected by her geographical isolation, NZ has not experienced the same level of impact from the recent "refugee crisis" as other parts of the world, and has responded with a small increase in the number of refugees resettled under the UNHCR resettlement programme - from 1000 currently to 1500 from July $2020^{6}$.

\footnotetext{
${ }^{4}$ https://www.education.gouv.fr/64-350-eleves-allophones-nouvellement-arrives-en-2017-2018-8-sur-10-etaient-deja-scolarises-4913

${ }^{5}$ While statistically a $72 \%$ increase in the inflow of foreign population seems substantial, the number of migrants is relatively small: from 57,618 new arrivals in 2010 to 99,321 arrivals in 2017. (OECD International Migration Database, https://stats.oecd.org/Index.aspx? DataSetCode=MIG Accessed 26/2/2020.
}

${ }^{6} \mathrm{NZ}$ Immigration, https://mstn.govt.nz/wp-content/uploads/2019/06/refugees-and-asylum-seekers-factsheet.pdf 
According to the 2018 census, 160 languages are spoken in Aotearoa NZ, with the six most common first languages spoken in New Zealand being English (95.4\% of people who stated speaking at least one language), Te Reo Māori (4\%), Samoan (2.2\%), Hindi (1.5\%), Northern Chinese (including Mandarin $2 \%$ ), and French (1.2\%) (NZ Census, 2018). The multilingual nature of the demographic continues to increase, with $18.6 \%$ of the population speaking more than one language ${ }^{7}$. Notably, Te Reo Mãori is widely taught in schools, with 278 Mãori immersion schools and $21.1 \%$ of the total school population enrolled in Mãori language classes in English medium education8 (Education Counts, 2019). The NZ linguistic landscape therefore reflects an English-dominated society, balanced however by the important place occupied by Te Reo Mãori as the indigenous language, and one of the three official languages of Aotearoa New Zealand ${ }^{9}$.

Languages spoken in NZ by number of speakers 2018

Other minority languages $(546,687)$

NZ Sign Language $(22,986)$

Pacific languages $(137,757)$

Te Reo Māori $(185,955)$

Asian languages $(204,228)$

* Indian languages $(408,978)$

English L1

Total population

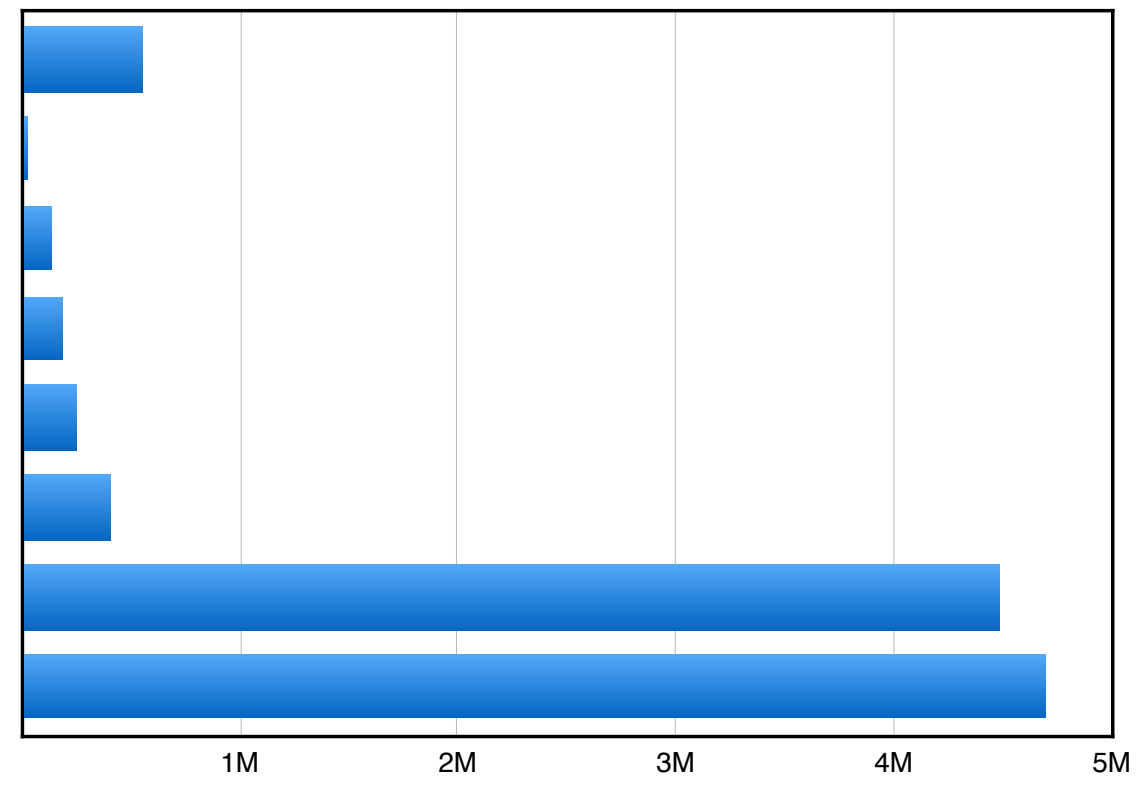

* Indian languages spoken = Hindi, Panjabi, Fiji Hindi, Gujarati

\section{(b) Plurilingualism in NZ schools}

New Zealand has three types of foreign students studying in schools: international fee-paying students (IFP), refugee-background students and students with a migrant background. IFPs come to NZ mainly from China, South Korea and Japan, paying high school tuition fees anywhere from NZ\$10,000 up to NZ\$18,000 per annum. Schools attach a host of services and related costs to IFPs, such as pastoral care, homestay and administration. NZ schools are eager to attract IFPs for economic advantages, and the income from 15,943 IFP enrolments in high schools in 2012 was NZ\$110.4 million nationwide. International student education is a rapidly rising market in NZ, which returned NZ\$2.6 billion to the GDP in 2012, and is ranked as NZ's 5th most valuable export (Education Counts, 2014). Newly arrived migrant and refugee students are eligible for government funding of NZ\$900 per annum to support their English language development for up to 5 years, and refugee students can apply for an additional 2 years of intensive funding.

What this picture of education for immigrant students in NZ tells us is two-fold: (1) there is an inequity in the perceived value among the three categories of immigrant students, with educational providers maximising efforts to attract IFPs for economic reasons, while refugee and migrant students represent a negative cost

\footnotetext{
7 Of these multilingualists, $60.4 \%$ were born overseas, and $39.6 \%$ were born in NZ. More than $50 \%$ of multilingual people live in Auckland city, reflecting the research on plurlingualism and ethnic diversity that centres on Auckland schools. 8 In secondary schools nationwide, 24,807 students were enrolled in Mãori language classes in 2018, and in primary schools all
students learn a little Mãori language and culture as part of the curriculum.

9 Skutnabb-Kangas (2003) makes for very interesting reading on the dangers of "linguistic genocide" when minority language speakers are taught through the medium of the dominant language, and first languages risk disappearing from one generation to the next. The linguistic revival of Te Reo Māori within the NZ education system is vital to the language's survival, and it is crucial that the Māori language be passed on to all children in NZ schools.
} 
deficit to the government; (2) this economic benefit attached to IFPs means that education for non-English speaking students has evolved significantly over the past 20 years, and as a result refugee and migrant children also potentially benefit from many of the resources that schools have in place for IFPs. As example, English language programmes have been developed nationally to make it possible for international students to gain high school qualifications and access NZ and overseas universities ${ }^{10}$. And therefore refugee and migrant students who are taking these English language classes also potentially benefit from the improved programmes and pathways to tertiary that have been put in place to attract IFPs. The question of inequity in educational provision amongst these three groups of immigrant students is increasingly urgent however, as multiple systemic and socio-demographic factors can negate "potential benefits" for refugee and migrant students, for example (i) low decile schools with high numbers of migrant students in areas that do not attract IFPs, (ii) lack of fiscal policy requiring schools to equitably dispense income from IFPs on second language learning support and resources, and (iii) the segregation effect of differentiated learning objectives and proficiency levels in English amongst newly-arrived refugee, migrant and IFP students that may result in little mixing through EL classes. Advocacy for refugee and migrant student education in NZ schools should therefore take into account existing inequities and make a stance for economic parity that brings more direct benefits to all EL learners.

\section{(c) 2nd language options in NZ schools}

Unlike the norm of plurilingualism as "a way of life" that is part of the European identity, New Zealand society is defined by cultural diversity yet linguistic domination by the monolingualism of an English-speaking society. Our self-ascribed national identity as a multicultural, inclusive, open society belies our reluctance to learn our community languages, a fact reflected in the statistics:

"Statistics from 2012-2013 show that 90\% of students in the European Union were learning a foreign language as opposed to only $27 \%$ of New Zealand students." (Johnstone, Morgan \& Warren, 2018)

Within this $27 \%$, language learning of the three languages spoken by three main groups of immigrants in NZ secondary schools has increased marginally between 2012-2018, with learners of Chinese up 50.9\%, learners of Spanish up 8.4\% and learners of Samoan up 3.6\% ${ }^{11}$ (Education Counts, 2018). The increase in the number of students learning Chinese is explainable by the China-NZ free trade agreement 2008, under which 147 Mandarin Language Assistants (MLAs) are currently teaching in schools throughout New Zealand, paid by the Chinese government.

The range of languages that students are offered (in addition to Te Reo Mãori and EL) is broadly representative of the largest immigrant communities living in NZ. High schools commonly offer two language choices from either the Asian languages family (Chinese, Korean, Japanese, Indonesian), Pacific languages (Samoan, Tongan, Niuean, Cook Island Mãori and "other unspecified"), and/or European languages (French, German, Spanish, Latin). The language group that is not yet being represented in second language choices is schools is the Indian family of languages, of which there are a significant number of speakers in NZ (1.5\% of the population speak Hindi, for example).

\section{Comparative summary: "National monolingualism dominates language diversity"}

In summary, both national populations in France and NZ can therefore currently be characterised as dominantly monolingual in the national language, with a diversity of immigrant languages spoken as community languages. The "social reality" of plurilingualism is witnessed by the number of languages spoken within the community, by a similar proportion of the immigrant population (about 20\%). However, languages within the education systems of both countries are to a great extent directed by an external political agenda - economic and trade-related, as is the case for the introduction of Chinese language

\footnotetext{
10 Immigrant students can gain credits towards NCEA literacy through English language units designed with international students in mind (EAP L4), and credits towards NCEA Level 3 certificate in the final year of high school (ESOL Level 3 unit standards).

11 Chinese in 2018 (5,814 learners) and in 2012 (2,849 learners); Spanish in 2018 (12,420 learners) and in 2012 (11.372 learners); Samoan in 2018 (2,342 learners) and in 2012 (11,372 learners).
} 
classes in primary schools in $\mathrm{NZ}^{12}$, and a preference for Asian languages as high school language options rather than Pacific languages. Similarly, France's political agenda reflects a regional alliance with the EU, and a Eurocentric preference for English and European languages in French schools over Arabic and other non-EU languages, despite the number of Arabic and African language speakers living in France.

\section{HOW INCLUSIVE ARE LANGUAGE EDUCATION POLICIES in FRANCE and NEW ZEALAND?}

\section{Plurilingualism as a contemporary social reality vs. Monolingualism in education}

As outlined statistically above, in both France and New Zealand, plurilingualism is increasingly a social reality, in that both societies are composed of significant numbers of people who speak languages other than, or additional to, the national languages. Translating this fact into education would mean that education systems could take a pragmatic approach to languages, in order to align themselves with the social reality of their linguistically and culturally diverse student populations. In this model, language inclusiveness asks that schools adapt approaches to learning so that students are speaking and hearing the languages they share amongst themselves, and does not necessarily ask for changes to the curriculum. Education systems that recognise the value of such a student-centred approach to teaching and learning will provide optimum linguistic opportunities for all students, including immigrant students, to access knowledge and succeed academically. It is thereby an approach to education that knows who our students are, and maximises learning opportunities by treating plurilingualism as a rich asset to be treasured, cultivated and capitalised on.

The Scandinavian countries (Finland in particular) are often cited as models of education systems that value second language acquisition and at the same time perform well in international PISA testing, raising interest amongst linguists and educators about correlations between plurilingualism and academic success (see for example Sinkkonen \& Kyttälä 2014; Jakonen-Kilpi 2012). However, the educational rationale here is clearly to work against a monolingualism that limits future prospects for young Scandinavians - the Finnish language being spoken only by the 5 million native speakers of Finland, learning other languages facilitates international opportunities. Conversely, an entrenched monolingualism in the education systems of France and New Zealand is supported by the global status enjoyed by both French and English - French as the official language of 29 countries, with an estimated 76 million native speakers, and English with approximately 400 million native speakers across 67 countries with English as the official language. The language inclusiveness argument for education in France and New Zealand is therefore based more on national social cohesion objectives: both are countries with high numbers of first and second generation immigrant students who speak a language other than the language-of-schooling at home (amongst first generation students $55 \%$ in NZ, 58\% in France; and amongst second generation students $41 \%$ in NZ, $31 \%$ in France (PISA 2018)). Furthermore, educational outcomes for certain groups of immigrant students continue to exacerbate racial divisions in future employment opportunities and limited socio-economic participation - notably amongst migrants from a Pasifika background in NZ (Ministry for Pacific Peoples 2018) and migrants from an Eastern European background in France (European Commission 2018). Where the Finnish model of education does offer an exemplar for other multicultural societies such as France and $\mathrm{NZ}$, is in the range of teaching practices and existing learning support structures around students that happen to also improve outcomes for immigrant students:

"Our results show that in addition to adequate lingual support, fluent co-teaching and co-planning in schools, utilising school assistants' working time and skills in various and creative ways have turned out to be effective for the learning and social integration of multicultural students."

(Sinkkonen \& Kyttälä 2014)

OECD studies into how immigrant students best succeed in education also support the view that educational environments have a responsibility to become informed about the specific needs of immigrant students, and to adapt in order to advantage learning processes and outcomes for this group (OECD 2015; OECD 2018). Educational objectives in increasingly linguistically, culturally and ethnically diverse societies such as New Zealand and France must therefore take into consideration not only the existing social fact of plurilingualism, but also the fact that current migration flows are profoundly changing the composition of classrooms:

12 The most popular language taught in NZ primary schools in 2018 was Chinese (64,874 students enrolled). The popularity of Chinese in primary schools is due to the Mandarin Language Assistant Programme, funded by the Chinese government under the NZ-China free trade agreement since 2010, under which 150 schools currently receive Chinese assistant teachers. https://ci.ac.nz/chinese-in-schools/ mla 
"PISA results reveal that in 2015, almost one in four 15-year-old students in OECD countries reported that they were either foreign-born or had at least one foreign-born parent. These numbers exclude the tens of thousands of refugees who have recently arrived in many of the countries that participated in PISA." (European Commission 2018).

Education's power to shape societies is enacted within schools, as sites of social interaction and the construction of societal norms. It is within schools that the complexity of multilingual and multicultural communities comes into daily contact, and as such schools have a formative role in cultivating social cohesion during this current context of immigration. A language inclusiveness argument positions the languages of plurilingual students, and language learning for all students (including language of schooling, heritage and second languages), as a key part of both immediate and long-term solutions towards social cohesion.

A language inclusiveness approach in schools serves three main purposes: (1) to support the learning and integration of immigrant students, particularly during their first year of transition into the school system; and thereafter to support ongoing plurilingual language and literacy development; (2) as continuation of linguistic heritage, either in the maintenance of heritage languages for descendants of immigrants, or language protection and revival of regional and indigenous languages; and (3) to create a language-rich learning environment in which all students have the opportunity to develop plurilingual skills. These three purposes clearly reflect the language competences of the whole student population, making language learning highly inclusive, offering the possibility of learning content through language, and acknowledging past, present and future linguistic aspirations for all children in schools.

\section{Where are languages within education policies for immigrant students?}

Underpinning the national languages debate in each country are the highly sensitive areas of Māori-pākeha biculturalism in Aotearoa NZ, and the still marginalised place of regional languages in France - both of which are hugely important and complex domains which address the language inclusiveness argument from the point of departure of language rights and self-determination (Durie 1998; Berryman 2008; Zarate, Lévy \& Kramsch 2008). The broader discourse on immigrant languages in education takes a slightly different focus in NZ and France: in NZ the interest tends to be in the revival and maintenance of community languages amongst second and third generation speakers (see Shameem 2003 for an overview of the NZ literature), while in France the national debate references the European context and research coming out of the Council of Europe Language Policy Division team (Beacco, Byram, Coste et al) on intercultural competence and developing plurilingualism through education.

Within the two different national contexts for languages, education policies for immigrant children and language learning are similar. Schooling objectives for immigrant children in both France and NZ are organised around learning the language-of-schooling (French or English respectively), and integrating children into monolingual school systems that do not specify a place for the immigrant child's first language in their education.

In France, of the 64,350 immigrant students identified in the 2018 national survey, 9 out of 10 of these had extra language support in the form of FLE (français langue étrangère) in UPE2A classes (Unités pédagogiques pour élèves allophones arrivants). The main objective of the child's schooling is mastery of the French language:

"Les modalités d'accueil et de suivi des élèves allophones arrivants doivent figurer dans les projets d'école et d'établissement, l'objectif essentiel étant la maîtrise du français enseigné comme langue de scolarisation... L'enseignement du français comme langue de scolarisation ne saurait être réalisé par le seul professeur de I'UPE2A : l'ensemble de l'équipe enseignante est impliquée."

(Ministère de l'Éducation Nationale, 2012)

[The processes of reception and ongoing support of immigrant students must be reflected in the school's educational projects, with the main objective being mastery of French as the language of schooling ... the teaching of the French language does not rest solely with the UPE2A teacher, but with the whole teaching staff.] 
Following entry testing which may be administered in the child's first language, the languages of immigrant children are thereafter rendered peripheral in the formal context of their schooling, because the languages they speak - Arabic, Portuguese, African languages, Romani and Eastern European languages - are not widely integrated into the education system as part of the curriculum. As importantly, pedagogy is not generally in use to facilitate the child's learning of content through the languages they speak, and opportunities for teacher training institutions to develop this kind of training need to be supported by education policy.

Similarly, in New Zealand's education policy for immigrant children, the National Education Goals, last reviewed in December 2018, omit to specify educational objectives for immigrant students and their languages. Rather, the rhetoric is general in terms of respect for diversity and cultural difference, leaving the inclusion of minority languages and the success of immigrant students in the English-dominated education system unarticulated as a national educational goal:

\section{"NEG 10 Respect for the diverse ethnic and cultural heritage of New Zealand people, with acknowledgment of the unique place of Mãori, and New Zealand's role in the Pacific and as a member of the international community of nations." (NZ Ministry of Education)}

In both French and NZ education policy statements therefore, we find an absence of plurilingualism, or bilingualism beyond Te Reo Māori, as a stated national educational goal. The language of schooling is prioritised, and while certainly essential for the immigrant child's success in schooling, the complementarity of inclusive language approaches is ignored. The effect on immigrant students is schooling within an education system defined by francophone / anglophone policies that prioritise monolingualism in the language of schooling, a selective approach to second language options, and exclusion of the wide diversity of minority languages spoken by the immigrant student population.

I explain this persistence of monolingual education policies in both educational environments, partly due to their rootedness in a historical principle upon which each education system has been respectively built - the principle of "social equity"13, and differing versions thereof in the French and New Zealand political ideologies.

\section{Social equity- an obstacle to language inclusiveness}

\section{(i) "Égalité" in France}

The languages of immigrant students are not given a place in their schooling experience, because in the entrenched concept of education in France, the language of schooling is French and French is the language of the Republic. This monolingual education policy is adhered to as a political inevitability of the philosophical basis of "égalité" underpinning French society - a social agreement that was forged during the revolution of 1789 , from which the French people won a trilogy of citizen's rights: liberté, égalité, fraternité (freedom, equality, fraternity). These rights have become enshrined in French constitutional law, and in the French mentality towards all aspects of public life. So from a material and pedagogical point of view, immigrant students have been viewed like all other students - they receive the same content knowledge and substantively the same learning trajectory. While French people may be united under the "one language" principle, immigrants and their languages are classified as "not French" in perpetuity (Schnapper 2007). This treatment of language diversity is a national issue that arises from constitutional law, and it is debatable whether French law will be reformed under pressure from increasing immigration and heightened international awareness of migrant rights and the responsibilities of each nation to integrate migrants in accordance with international standards of care and protection. However, France is also a key member of the European Union, and as such adheres to a "European community" identity that is not indifferent to the principles of language inclusiveness as promoted by the Council of Europe.

As a prominent example, the Council of Europe's Languages in Education/Languages for Education (LE) project 2006 highlights the benefits for all children, not only children from ethnic and cultural minorities, in learning languages and being exposed to language diversity in schools. The LE project reduces the

\footnotetext{
${ }^{13}$ For an overview of social equity and cultural inclusiveness policies in NZ education during the 1990s restructuring, see Middleton, S. (1992) Equity, Equality, and Biculturalism in the Restructuring of New Zealand Schools: A Life-History Approach. Harvard Educational Review: September 1992, Vol. 62, No. 3, pp. 301-323
} 
distinction between local children and migrant children, taking the view that languages provide fertile learning ground on which there is the possibility of constructing a shared "cultural and information capital". The LE project advocates for plurilingualism as a social reality (Plurilingual and intercultural education as a project, 2009), stating that regardless of how education systems may construct hierarchies of languages that give preference to some over the exclusion of others, languages simply exist in the social realm and are a fact of everyday life. This view aims to deconstruct systemically established language hierarchies, pointing out the pragmatism of including multiple languages as part of the reality of social diversity.

\section{(ii) "Social equity" in NZ}

Similarly, the NZ education system has evolved out of a specifically New Zealand notion of equality - a form of "social equity" through diversity, rooted in our colonial history as a nation built by immigrants within the framework of Māori-pākeha bicultural relations (Middleton 1992). In the NZ context, assimilationist policies of the past colonial era ${ }^{14}$ have been challenged and partially dismantled by the renaissance of Mãori language and cultural practices in education since the 1980s. NZ's identity as a constitutionally bicultural nation, and the protective rights safeguarded by Mãori under the Treaty of Waitangi 1840, provide a unique political context around the language inclusiveness debate in NZ, articulating a clear rationale for linguistic and cultural preservation that is even more important in the case of indigenous languages:

"Māori is the foundation language of New Zealand, the ancestral language of the tangata whenua and one of the taonga guaranteed protection under the Treaty of Waitangi. It also provides this country with a unique language identity in the rest of the world, as this is the only place where Māori is spoken widely... human freedom is dependent at all levels on choice and diversity; linguistic pluralism can be nothing other than a guardian of individual freedom and identity against the forces of conformism."15 (NZ Human Rights Commission)

While immigrant languages cannot expect to be accorded the same status as Mãori in NZ, the political landscape in terms of language inclusiveness has been fundamentally shaped by the progressive routes carved out for Mãori language since its official recognition in 198716, and subsequent revitalisation through immersion schooling and early childhood education. Mãori language therefore paves the way for immigrant languages to find a stronger foothold in national policy direction addressing the integration of immigrants, linguistic pluralism as part of individual freedom, and the education of migrant children in NZ schools (Hornberger 1998; May 2005; Barkhuizen et al 2006; Kepa and Manu'atu 2006). NZ research acknowledges the importance of Māori language as the defining context for future developments in language education in $\mathrm{NZ}$; while at the same time underlining tangata whenua concerns about how new policies to formally include and protect immigrant languages may be problematic for Māori:

"Māori have argued consistently for the right to self-determination for, in effect, separate recognition by the state of Mãori political culture and social organisation, and for the recognition of the cultural and linguistic distinctiveness of Māori. These arguments have been expressed via the political notion of biculturalism, and via an associated rejection of multiculturalism with its intrinsic 'levelling' of the claims of all ethnic minority groups. Rather, Māori argue that multi-culturalism, in practice, would simply work in favour of the numerically dominant Pākehā group. Minority groups would be encouraged to fragment and to compete with one another for limited resources, thus maintaining current Pākehā dominance in Aotearoa/New Zealand (Spoonley, 1993)." (May 2005)

Clearly, the social equity debate in NZ springboards from Māori indigenous rights, and is flavoured by conflicting interests and concerns where the debate extends to multiculturalism and immigrant language rights. A further area of tension is expressed in the role of language in integration processes for newlyarrived immigrants in NZ (English acquisition vs. maintenance of immigrant languages). Smythe (2018) points to embedded power relations in integration processes, and social equity questions within the languages debate:

\footnotetext{
141867 Native Schools Act decreed that English should be the only language used in the education of Māori children.

15 The NZ Human Rights Commission was set up in 1977, and is funded through the Ministry of Justice but operates independently of the New Zealand Government as an independent Crown Entity, https://www.hrc.co.nz/your-rights/your-rights1/maori-language-history/

16 The Māori Language Act 1987 declared Mãori to be an official language of New Zealand, alongside English.
} 
“... the physical displacement and 'pepper potting' of minority language speakers amongst an English speaking majority poses a threat to intergenerational language transmission. For former refugees, the process of settling into a new country can be accompanied by a loss of identity and feelings of powerlessness (Altinkaya \& Omundsen, 1999). A languages policy recognising the need to acquire English but incorporating protections for community languages would address many of the power disparities that underpin language loss, and in doing so bolster the self-identity of the groups that speak them (Warren, 2017). While gaining proficiency in English, either through the schooling system or as a second language for adult migrants is inarguably necessary for successful integration and accessing social services in an English dependant society, the bolstering of minority languages against irreversible language shift and the provision of interpreters for non-English speakers is tied to both economic growth, citizenship rights and a sense of belonging for refugee background communities."

We hear therefore, that there are multiple viewpoints to consider in the social equity debate in Aotearoa NZ. The Māori experience has been unique amongst the colonised peoples of the world, as something of a postcolonial success story. However, the fight for equal recognition and participation has not yet been won, and Māori are living this daily. The fear of fragilisation and fragmentation of the hard-won political ground in Māori indigenous rights is real; and at the same time, the new reality of waves of immigrants arriving with their own sets of concerns, rights and interests is also valid. The question for integration and language politics in NZ right now, is how to honour and protect the language revival (also termed "language reversal", Paulston 1993) of Māori, and the special status occupied by the indigenous language and culture of this land; while now creating new spaces in the language rights domain for the inclusion of migrant languages and the integration of our diverse immigrant cultures. This will need to be approached with sensitivity to the plurality of interests at work on the terrain, in order that an equitable power balance be established that appropriately reflects the multiplicity of our social responsibilities as a diverse society.

We can conclude that language diversity, as an aspect of integration, is currently in a state of forward momentum in NZ. New research is advocating for improved services for immigrant communities that accentuate a multilingual public environment - for example, greater support from government for effective translation services for newly-arrived refugees, as an essential part of the settlement process (Smythe 2018). Similarly, there is strong advocacy for Pasifika languages to occupy a key role in improving educational outcomes for Pacific Island children, through bilingual education that follows a similar model to Māori bilingual education (May 2009). In the NZ languages landscape, the growth of Māori bilingual and immersion schooling since the 1980s, and the consequent positive outcomes educationally for Māori children are an exciting reference point for all language learning. It remains to be seen whether there will be flow-on effect from which immigrant languages can claim space within the education system in such a way that newly arrived immigrant children are supported in their initial learning of English, and settled immigrant children have avenues for maintaining their languages of origin.

\section{Comparative summary: two versions of social equity in France and NZ}

We can characterise these two forms of social equity respectively as a French "égalité" that avoids making distinctions between immigrants and the local population as it would be a form of negative discrimination, yet finds itself challenged to effect a transition in response to the integration needs of its immigrant population; and a New Zealand version of "social equity" that positions diversity as the social norm of a young society with an immigrant past, and that is still struggling to evolve in response to the multiple and complex realities of its bi-multicultural present.

How then to define "equity" in education, as an objective standard that encapsulates these two versions of "égalité / social equity"? Equity in education is underpinned by two premises about children and education:

“... first, that education significantly influences a person's life chances in terms of labor market success, preparation for democratic citizenship, and general human flourishing; and second, that children's life chances should not be fixed by certain morally arbitrary circumstances of their birth such as their social class, race, and gender." (Stanford Encyclopaedia of Philosophy)

This definition of "equity in/through education" is concerned with maximising chances for equal outcomes for all students; that education has the power to supersede social and individual circumstances, and that educational equity is about systemic and pedagogical approaches that recognise diversity, individuality and future aspirations, thereby empowering each child's "life chances". Language inclusiveness, in the current context of more linguistically diverse schools, can be positioned as a component of "equity in/through 
education". Education pathways that include immigrant languages maximise opportunities for immigrant students, and in cases where languages are prioritised in national curricula, the child gains a potentially powerful learning tool with which to overcome learning barriers inherent in the migration experience.

\section{DEGREES of LANGUAGE INCLUSIVENESS in EDUCATION CURRICULA}

How are educational environments responding to greater numbers of newly-arrived plurilingual students in schools, as well as the demand for language inclusiveness from established immigrant communities?

\section{France: centralised education curriculum leads to systemic language exclusion}

In France, educational policy and practice work together when the child is enrolled in school, with importance placed on welcoming parents, facilitating communication through the home language, and understanding the child's prior schooling experiences in his/her first language. Once these measures have been met, schools have some latitude in the child's schooling, which may include French language classes with other UPE2A students and a French teacher who acts as an initiator for the child's integration into school during the first year. The initial reception phase is therefore marked by a high level of language inclusiveness, with home languages playing a significant role in establishing communication between school, parents and the newlyarrived child.

Authors Cherqui and Peutot take a critical view of language inclusiveness in French schools, in their 2015 publication "Inclure: français de scolarisation et élèves allophones". Stating that "l'école français a toujours été très mal à l'aise vis-à-vis des langues-cultures premières des élèves" [schools in France have always been very uncomfortable with the languages and cultures of origin of their students], the authors postulate reasons for this French discomfort with including the languages and cultures of immigrant students, which I expand on as follows:

1. The teaching of French as the language of schooling is legitimised by the Republican principle of égalité. Within the current debate pushing for change in the education system, the concept of "égalité" is again under criticism on the basis that all children are treated equally but this in itself excludes immigrant children from recognition of, and capitalisation on, their existing linguistic and cultural knowledge (Beacco and Byram 2007; Coste 2012).

Systemic structures that see equity as "one size fits all" tend to result in inequitable achievement outcomes for particular groups of students who become in effect excluded through a lack of support for their specific learning needs. This is a point for continuing, context-specific research in the field of comparative education, as it impacts significantly on the schooling experiences and achievement outcomes for immigrant children.

Language policies for foreign language teaching further exclude the languages present among the immigrant student populations of schools. That is, English continues to be the dominant foreign language taught in French schools, with German occupying second place. Other languages which form part of students' linguistic and cultural repertoires are not recognised in the national school curriculum.

This situation is very common throughout education systems worldwide and evident in national education programme choices in foreign language options, which tend not to include a range of immigrant languages. The constraints of time and resources necessitate choices in school curricula that cater for the educational benefit of the majority and follow national policy guidelines. The question returns to "whose objectives are being served by educational policy, and whose interests are being minimised or ignored in school curricula?" A political view of language education in schools sees that educational policy is state-centred, and directed by political objectives in international relations, such as trade, diplomacy, and foreign affairs, rather than student-centred and for the development of the individual. This has led to education systems that are designed to produce citizens equipped to enable the political objectives of the country, rather than individuals skilled in a range of linguistic and cultural competences that reflect the pursuit of self-developmental goals through education. While the two are not mutually exclusive, the political agenda by which school curricula are determined allocates a disproportionate amount of time and space to a limited selection of languages, with the result that education is preoccupied with one or two dominant foreign languages, to the detriment of other language options. Immigrant languages suffer particularly under these types of education policies, as Bulgarian, for 
example, is as rich a language to learn as English, yet is not taught in French schools as it has little perceived value for France's current political objectives.

3. The French education system demonstrates a selective attitude towards languages which is hierarchical, with English seen as a useful language, while African, Arabic and Eastern European languages are viewed as of little value and therefore ignored within the school curriculum.

The educational objectives of language learning have therefore become removed from the pedagogical intention that learning any language develops the learner cognitively, emotionally and socially. Instead, a hierarchical view of language learning is in place which is about aligning the learner with certain language communities - predominantly, the global community of English speakers. This communicates to children in schools, and to society at large, that minority languages are not worth learning, as the people who speak those languages are not part of a community that "we" seek to participate in.

To sum up, the French national Ministry of Education bulletins on the education of immigrant children have required schools since 2002 to include the child's home language in the administrative phase of the child's integration into school life. As critiqued by Cherqui and Peutot, a systemic language exclusion characterises the French public education system, in that languages are subjected to a hierarchical rationale with the language of schooling at the top (compulsory for everyone), a limited selection of second languages in the middle dominated by English (as foreign language options), and immigrant languages at the bottom (rendered inaudible and invisible in formal learning, however present in the playground and in the lives of immigrant students).

\section{New Zealand: open curriculum leads to "patchy" language inclusiveness practices}

In practice in NZ schools, a comparatively wide range of languages are offered as optional subjects in secondary schools, however language learning is not compulsory, unlike in France where students are expected to learn two foreign languages during their schooling. The "Learning Languages" strand of the 2007 NZ Curriculum allows schools to choose which languages they teach either as second languages or as the language of instruction in partial or full immersion, depending on community need and teacher skills. For example, of 39 schools offering Samoan language classes, 21 are in Auckland where there is the highest density of NZ's Pasifika population (NZ Ministry of Education, 2008). As with Mãori language classes, $95 \%$ of students taking Samoan language classes are doing so to maintain their first or heritage language. The national approach to learning languages appears to be, on the surface, relatively inclusive, however while the curriculum potentially enhances opportunities for language learning through its broad and open approach, in practice it continues the legacy of "an empty promise" that dogged its predecessor, the 1993 curriculum framework:

"A central limitation of this document is that it offers everything to everyone, but does not describe just what will actually be provided by schools. There was also no pressure on schools to provide language programmes for ethnic minority groups." (Hill, 2010, p.36)

To redress the limitations of the curriculum's language provision, there are two domains in which language inclusiveness within education can be developed and strengthened: (i) state schools and the degree to which immigrant languages are included as language options within school programmes (as second language or first language maintenance), and (ii) bilingual or immersion schooling.

State schools

Most NZ state schools have highly diverse student populations, and in urban areas with high density plurilingual immigrant populations there is increasing recognition amongst school leaders of the importance of including and celebrating this diversity as the key to educational success for minority student groups. As an example, Avondale College is an Auckland school with a student population of 3000 , of whom $40 \%$ are Mãori and Pasifika students alongside another significant proportion of migrant and international students. The school recently gained accolades for student performance both academically and in cultural events, and attributes its success to inclusive approaches in which diversity provides a platform for students to engage with and embrace each other's differences: 
"I think students are advantaged [here] by the mix," [the school principal] said. "Modern New Zealand is diverse and the youngsters who are put in a safe, positive, exciting environment where those things are celebrated are going to be the most personally powerful people in New Zealand's future." (Radio NZ, 9/6/2017)

Within state schools where the language-of-schooling is English, the potential for working with minority languages through the language learning strand is limited by the status of the English language. English is increasingly institutionalised as not only an official language of NZ and the dominant language-ofschooling (May 2006), but also now as a global lingua franca. In spite of NZ's geographical isolation and small population, national education policies reflect anglocentric attitudes towards English as the language worth mastering, along with implied advantages to the individual in terms of mobility, enhanced economic participation and future opportunities. Evidence of this attitude is visible in the predominance of monolingual English-speaking teachers in NZ schools (Hill 2010), and the lack of emphasis within teacher training programmes on building language content knowledge and pedagogical skills in second language teaching, outside of Te Reo Māori (Hill 2010; Richards et al undated).

Within the NZ state school context, greater inclusion of Pasifika languages should be prioritised, and in support of this more research needs to be carried out in NZ to understand links between first language literacy development and school achievement. Again, successful outcomes for Māori students is a point of departure for the language inclusiveness argument for Pasifika students:

"The work in the revitalisation of te reo Māori over the past 30 years within the state school system has forged a path for schools to equally look to supporting the teaching and maintenance of Samoan, Tongan, Cook Islands, Niuean and Tokelauan heritage where their communities have reflected these Pacific language groups." (ERO 2019)

To sum up, the issue of relative marginalisation of immigrant languages in NZ state schools stems from the hierarchical relationship between English as a majority language and other minority languages, which is an historical, social and political process that is "deeply imbued in wider (unequal) power relations" (May 2006, p.260). I add that modern social and political conditions around immigration lend urgency to the debate on immigrant language inclusion in schools, particularly as support for student integration and English acquisition during the newly-arrived phase. There is a need as never before for educational policies and practices that recognise the multiple social intentions and learning objectives of language inclusiveness. This is an area with strong potential for development within NZ schools, as the open curriculum offers opportunities through structured inclusion of minority languages, both in second language programmes (where numbers of learners allow) and within EL programmes to link existing L1 skills to English learning. For either of these areas to be effective, schools need to be resourced with bilingual teachers, materials to support second language programmes, professional development in languages pedagogy, and perhaps most importantly, innovative school leaders and teaching staff who see the value of language inclusiveness and have a vision beyond the English monolingual model.

(ii) Bilingual and immersion schooling in NZ consists, in the main, of 290 Māori bilingual schools (July 2019, Education Counts) and 30 schools providing bilingual Pacific language education in Auckland (August 2019, ERO). The research consensus is that bilingual schooling programmes have been shown to be highly effective for both Māori and Pasifika learners, yet there is insufficient government support for existing programmes, let alone expansion and replication of what is working in education for Pasifika students (Kepa and Manu'atu 2006; Tuafuti and McCaffery 2005). This amounts to "subtractive views of bilingualism among the monolingual English-speaking population" (May 2005) - that is, the conviction that bilingual approaches to learning represent a deficit to proficiency in the majority language, whereas international findings unequivocally support the fact that bilingual and plurilingual children do better in education where their languages are included in school-based learning (Corson 2001; Cummins 2001; Coste et al 2012). The current challenge is for government, schools and immigrant communities to work together to strengthen existing bilingual school programmes, around objectives of better outcomes for bilingual students through developing their linguistic and cultural capital in ways that can be applied to advantage social, economic and political participation as future adults. In support of this challenge, ERO found in 2019 that:

“... Pacific bilingual education programmes were somewhat idiosyncratic. They tended to be developed locally, and were resourced out of schools' baseline funding. Schools expressed a general philosophy regarding the importance of Pacific languages, culture and identity, but were less 
likely to have developed an approach focused on bilingualism and informed by research literature and best practice." (p.4)

This points to the need for government to support professional development for bilingual teachers, and for universities to develop initial and ongoing teacher training programmes in both language content and pedagogy for working with immigrant students and their languages in the classroom. In addition to action from government and teacher training institutions in support of bilingual education, the school-community partnership aspect is also key. The kohanga reo movement has demonstrated that strong community relationships foster both inter-generational sustainability and quality of bilingual and intercultural education:

"In Aotearoa New Zealand it has become clear that programs started by people in a community are a better possibility for robust partnership and practice in education. In fact, Indigenous Māori grassroots work to establish Te Kõhanga Reo: Early Childhood Education conveys this point well. ... partnership and practice are enmeshed in social networks that emphasize the richness of Māori language and the complex ways Māori people live their lives." (Kepa and Manu'atu 2006)

It is clear that bilingual education for Māori and Pasifika students has very important and ongoing work to do in forging pathways into the somewhat resistant landscape of educational policy and practice in NZ. In order for language inclusiveness to make headway in the NZ education system, a shift away from monolingual English-speaking complacency towards research-informed understanding of the advantages of bilingualism and plurilingualism is required.

To sum up, the national picture of language inclusiveness is patchy in NZ. The National Curriculum is very broad and permissive in terms of its recommendations for language learning. Second language learning, EL and first language maintenance are grouped together in a single curriculum learning area, which has the advantage of allowing schools to make choices that suit the language learning needs of their community, but the disadvantage of pedagogically undifferentiated learning goals. That is, the needs and aspirations of immigrant students in maintaining their heritage language may not be given priority until that immigrant student population reaches a certain critical mass, and a demand for language maintenance and inclusion of cultural practices is acted upon by the school, as is the case at Avondale College. The challenge is for schools to take innovative approaches towards including the languages of their immigrant students in school programmes, working in partnership with ethnic minority communities and parents, and for government to resource and support these innovations to maximise chances of success. Articulating the past-presentfuture link as objectives in bilingual education is essential, as "heritage" (past-orientation) and "maintenance" (present-orientation) are often stated as part of the rationale for language inclusiveness, but future opportunities for plurilingual citizens of NZ is a goal that signifies participation with deeper implications for Aotearoa New Zealand's social evolution as a whole.

\section{Comparative summary: \\ "In both France and NZ, languages fall prey to education agendas that are politically imposed."}

In summary, an overview of language inclusiveness in schooling in France and NZ shows us two different examples of how educational policy and practice work together to create particular outcomes for immigrant students. In France, educational policy for immigrant students is more explicit and developed. There are a number of national circulars issued by the Ministère d'Éducation that set out guidelines and rules for the schooling of immigrant children ${ }^{17}$, which is governed by CASNAV (Centre Académique pour la Scolarisation des Nouveaux arrivants et des Voyageurs). However, while at a national organisational level education policy is significantly developed, in school practice plurilingual educational approaches for immigrant children are not developed, and as a result there is a significant gap between the social reality of plurilingualism in schools and the limitations that are imposed on schools in their ability to respond to the language diversity of their student population. In particular, the small number of European languages offered means that the languages mainly spoken by the immigrant population are excluded. The outcome is an education system that is selective of the languages that are included in schools, with glaring blind-spots in terms of several significant groups of immigrant students and their languages - at the top of the list being Arabic.

In NZ, education policy is more developed for some groups of plurilingual children who have been identified as either at risk of failure in the education system, or who offer an economic incentive. There are currently

${ }^{17}$ For example, Organisation de la scolarité des élèves nouvellement arrivés en France, C. n 2002-100 du 25-4-2002 
three groups who are privileged by specific educational policies: Mãori children, with significant support for language and cultural immersion education as essential in the protection of our indigenous language for future generations; Pasifika children, with a focus on raising achievement outcomes in the public school system; and international fee-paying students, with a focus on economic incentives and education as service provision. There is also a support network around the educational and integration needs of refugee children, from both government and NGOs in NZ18. Overall, educational policy for immigrant children as a cohort is underdeveloped in NZ, but the broad nature of the school curriculum allows schools to make choices in language learning and cultural activities that can address some of the needs of immigrant students, if applied. As a result, a wide range of world languages are taught in schools (17 languages in 2018, excluding English), meaning that some immigrant students gain access to their first language as part of their education. However, with more than 160 immigrant languages spoken nationally, there are many students in the education system whose plurilingual development will not be catered for at school. The end result is an education system with aspirations towards language inclusiveness, but without the means and resources to formally realise this in the education of every immigrant child.

So it can be said that in both France and New Zealand languages fall prey to education agendas that are in both cases politically imposed, rather than incorporating and maximising the potential of existing linguistic and cultural capital within the populations. This results in forms of language exclusion in both countries. Again, a political view of languages in schools sees that minority languages that are present in the student population are forced to occupy peripheral space outside of the school curriculum, remaining relegated to the playground and the family home; and this language exclusion may impact on students' educational success over time. In both countries there are untapped solutions to explore, beginning with a shift away from monolingual language-of-schooling perspectives towards a view of "languages in schooling" as beneficial for all students.

\section{CHANGES SIGNALLED in 2020: CONCLUSION}

So in 2020, what kinds of changes are being signalled in the response from educational environments to plurilingual students in schools, with a view towards language inclusiveness and recognition of plurilingualism as a social fact ? In 2020, a new phase of educational evolution is being signalled in response to the societal fragmentation experienced in a France who can no longer ignore the linguistic and cultural diversity of her immigrant population. In New Zealand, immigrant communities are verbalising their wish for state recognition of their languages and cultures, to foreground the contribution that each makes to the linguistic and cultural tapestry that characterises Aotearoa New Zealand. In both countries, there is visible movement towards a more language inclusive educational environment, stimulated by the presence and needs of newly-arrived and established immigrant communities. In both countries, the social fabric is changing, and there are multiple effects from this:

1. These new and existing types of immigrants have particular educational needs in language learning (be it learning the national language, and/or maintaining their languages of origin). Governments will have to respond to these needs, and we see that in the case of NZ there is an enthusiastic government response to IFPs accompanied by the incorporation of a new set of educational formulae to attract the economic advantages of the international student market. English language teaching and learning will be an area for ongoing development, as well as training teachers in intercultural communication and inclusive language pedagogy (Shameem 2003; Gleeson \& Tait 2010). In the case of France, asylum seekers and refugees represent a cost deficit to the government, which is being managed through law and policy change since 2016 to limit the number of refugees resettled. In the education system, French education policy is not yet proposing additional support for refugee children, although there are university initiatives to help refugee students successfully integrate into tertiary education ${ }^{19}$.

2. Immigrant communities already established in both countries, who represent a significant linguistic proportion of the immigrant language groups spoken, are asking governments for greater recognition of

\footnotetext{
18 Notably the NZ Red Cross

${ }^{19}$ For example, at the University of Bordeaux a student-initiated buddy programme for refugee students, Sept 2018: "Pour aider ces migrants dans leur trajectoire, le réseau universitaire « Accueil et Intégration des Migrants et des Exilés » (AIME : http://reseau-aime.fr) organise et anime un accompagnement par des étudiants. La mission de ces étudiants dits " compagnons ", est d'offrir aux migrants l'opportunité d'échanges culturels informels avec des étudiants francophones déjà intégrés dans l'enseignement supérieur."
} 
their languages and cultures. In France, there is a readiness as never before for the Arabic language to find a formalised place within the education system. This has enormous potential for altering the linguistic landscape of French education at all levels: the teaching of Arabic in schools would signify the inclusion of all Arabic-speaking children, as well as opening the way for intercultural dialogue and the plurilingual development of French children through a language that has long been a part of the French social composition (Blanquer 2018). It may follow that the Arabic language will become legitimised as part of university teacher training programmes, with the highly desirable outcome that native speakers of Arabic will have their existing bilingual skills validated as part of their Masters in Education degree. Currently, teachers must demonstrate proficiency in a second European language in order to qualify as a teacher, and although they may be fluent speakers of Arabic or other non-European languages, to date these languages have not been admissible in the teacher training qualifications organised through French universities. The question of "cultural inclusion" and Arabic-speaking communities is complicated by the law on laïcité in France - the separation of religion from public life. The inseparability of Islam from the Arabic language presents an ongoing dilemma for French authorities - how can the Arabic language be included in education while French law insists on secularity? Far from a process of intercultural negotiation to achieve a mutually agreeable solution to this dilemma, Schnapper (2007, p. 12) describes the situation as a state-imposed French form of "intégration", that refuses to take into account the diversity of cultural identities, instead adopting the term while not moving far from the old assimilationist practices. The debate is ongoing, and exacerbated by shared histories of colonisation, terrorist extremism and immigration.

3. In Aotearoa New Zealand, Pasifika people are asking for formal recognition of 5 Pacific Island languages by the government, as a way of honouring the particular history of generations of PI immigrants who have settled in NZ. The Pacific Languages Framework sees this as a way in which: "Pacific peoples' sense of personal and cultural belonging in New Zealand will be enhanced by the support given to Pacific languages. New Zealanders will appreciate and value Pacific languages as a source of pride in New Zealand's rich cultural diversity" (Ministry for Pacific Island Peoples, 2018). The link between language and sense of intercultural belonging is fundamental to the identity of successive generations of Pasifika peoples in NZ, as expressed by the Minister for Pacific Peoples:

\section{"...for us as Pacific people, language is an important bridge between our place in modern New Zealand and our story as Pacific Islanders." (Aupito William Sio, 3/8/2019)}

For Pasifika children, classified as underachieving in national education statistics ${ }^{20}$, this opens up the possibility of pursuing pathways in education that are supported by teaching and learning in their first languages, with the potential for improved outcomes in education. There is a clear language inclusiveness argument being made in NZ right now, that references Te Reo Māori and seeks the autonomy of community-based approaches in education, with government support.

I argue that in 2020, in both France and NZ, new spaces are being opened up for languages in education, that may result in greater inclusion of migrant languages in the educational environment. Both countries are in tentative transition towards change in terms of educational policy and practice in language education, in response to the social realities of their plurilingual populations. Is this however indicative of new paradigms emerging that recognise the benefits of plurilingualism and language inclusiveness in education? While this would be highly desirable and indeed exciting for the future of education in countries with highly diverse populations, such as New Zealand and France, the transition is still in negotiation phase. The political "enjeux" is one of a delicate tension between resistance and facilitation; change is inevitable at this time of remarkable migratory movements of people, and governments have challenging choices to make in how new immigrants are resettled, how existing immigrant communities are more deeply integrated, and how local populations can live social change positively. The two-way social and educational benefits of language inclusiveness are yet to be fully understood, but offer us considerable scope for developing directions in education that create education policies and practices that include the languages of our immigrant populations, thereby (a) striving for social equity in education that can yield better educational outcomes for immigrant children; (b) adopting new perspectives on languages in teacher training that include the formal training of school teachers in plurilingual pedagogies; and (c) encouraging deeper forms of intercultural understanding and cohesion in societies as a whole, through more equitable exchanges of linguistic and cultural capital.

\footnotetext{
20 In 2016, 43\% of Pasifika learners left high school with a qualification at NCEA Level 3 or above, which is $11.8 \%$ below non-Pasifika students. https://www.educationcounts.govt.nz/topics/pasifika education/pasifika-education-plan-monitoring-report
} 
In both European and NZ language policy, the recommendation for plurilingual education is legitimised by a multi-pronged examination of long-term social contexts and historical outcomes for migrants. Entrenched stereotypes around immigrants persist both statistically and in the national psyches of France and NZ (Schnapper 2007; Ward and Liu 2011), and education systems have a major task ahead in transforming these limiting portrayals into success stories. Problems of socio-economic segregation of immigrant populations, ensuing cycles of poverty, and the disadvantages stemming from unequal access to higher education, and subsequently employment, are consistently identified as systemic social problems that can be mitigated by an educational environment that prioritises language skills (OECD, 2015). Language, both as a primary communication tool enabling participation in the host society, and as a vehicle for moving linguistically between the two cultural worlds occupied by immigrant children, should therefore be placed at the heart of future policy direction for the educational success of immigrant children in both countries.

\section{Acknowledgements}

I thank the two schools in Bordeaux and Wellington who participated in the study that contributed to the PhD research. I thank reviewers of the New Zealand Journal of Educational Studies for their feedback.

\section{Notes on author}

Fiona Smythe is a doctoral researcher of Sciences d'Éducation at the Universite de Bordeaux, Bordeaux, France, under the supervision of Dr. Régis Malet. Since 2019 she has been ATER (attaché temporaire d'enseignement et de la recherche) with the Département Langues et Cultures at the Université de Bordeaux.

\section{References}

Abutalebi, J. (2016), Neuroimaging of language control in bilinguals: neural adaptation and reserve, Bilingualism: Language and Cognition 19 (4), 2016, pp. 689-698

Auger, N. (2011), S'appuyer sur la compétence plurilingue-pluriculturelle des élèves allophones nouvellement arrivés en France pour favoriser l'entrée dans le français : La classe de langue entre théorie et pratique, Le Langage et l'homme, Vol 46, Num 2, pp 73-84

Barkhuizen, G. et al (2006). Language Practices, Preferences and Policies: Contrasting Views of Pakeha, Maori, Pasifika and Asian students, Journal of Multilingual and Multicultural Development, 27 (5), 375-391

Beacco, J-C (2005). Languages and Language Repertoires: Plurilingualism as a way of life in Europe. Language Policy Division, Council of Europe, Strasbourg

Beacco, J-C and Byram, M. (2007). Guide for the Development of Language Education Policies in Europe: From Linguistic Diversity to Plurilingual Education. Council of Europe, Strasbourg

Berry, J. W. (1997). Immigration, acculturation, and adaptation. International Journal of Applied Psychology, 46, 5 - 34.

Berry, J. W., Phinney, J. S., Sam, D. L., \& Vedder, P. (2006). Immigrant Youth: Acculturation, Identity and Adaptation. Applied Psychology: An International Review, 55 (3), 303-332

Berryman, M. (2008). Repositioning within Indigenous Discourses of Transformation and Self-Determination. PhD thesis, School of Education, University of Waikato, NZ.

Berthoud, Grin, Lüdi (eds) (2013). Exploring the Dynamics of Multilingualism: The DYLAN project. John Benjamins Publishing Co., Amsterdam

Bialystok, E., (2011), Coordination of Executive Functions in Monolingual and Bilingual Children, Journal of Experimental Child Psychology Nov 2011; 110(3): 461-468.

Byram, M., Nichols, A., and Stevens, D. (eds) (2001) Developing Intercultural Competence in Practice. Clevedon: Multilingual Matters. 
Cherqui, G. \& Peutot, F. (2015). Inclure: français de scolarisation et élèves allophones. Hachette Français Langue Etrangère

Corson, D. (2001). Language diversity and education. Mahwah, NJ: Lawrence Erlbaum

Coste, D. (dir), (2012). Les Langues au Coeur de L'Éducation: Principes, Pratiques, Propositions. ADEB (Association pour le développement de l'enseignement bi-/plurilingue)

Coste, D., (Nov 2019). 'Le bi-plurilinguisme dans l'éducation: Enseigner et apprendre en plusieurs langues - valeurs, principes didactiques, gestes professionnels, ressources' presentation at ADEB Symposium at INALCO. Attended 23/11/2019.

Council of Europe Action Plan (Sept 2016). Integrating refugees and migrants through education: building bridges in divided societies.

Council of Europe Action Plan (2009). Plurilingual and intercultural education as a project.

Council of Europe Language Policy Division (2010). Migrant Children Concept Paper.

Cummins, J. (1979). Linguistic Interdependence and the Educational Development of Bilingual Children. Bilingual Education Paper Series, Vol. 3 No. 2

Cummins, J. (2001). Bilingual Children's Mother Tongue: Why is it important for education?. Sprogforum 19(2), pp15-20

Cummins, J. (2001). Language, power and pedagogy: Bilingual children in the crossfire. Clevedon, England: Multilingual Matters

Dalgalian, G., (Nov 2019). 'Le bi-plurilinguisme dans l'éducation: Enseigner et apprendre en plusieurs langues - valeurs, principes didactiques, gestes professionnels, ressources', presentation at ADEB Symposium at INALCO. Attended $22 / 11 / 2019$

Dubet, F., (2010). Les Places et les Chances: Repenser la justice sociale. Éditions de Seuil et La République des Idées

Durie, M. (1998). Te Mana, Te Kāwanatanga The Politics of Self Determination. Oxford University Press, Auckland NZ

Ebersold, Serge, (quoted in presentation by Rigoni, Isabelle, Nov 2019), "Les facettes de l'inclusion au prisme de l'hétérogénéité des EANA", in presentation at Université Bordeaux, ADEB journée d'étude, 20/11/2019

Education Counts, NZ Statistics, NZ Government. https://www.educationcounts.govt.nz/statistics/maori-education/maoriin-schooling/6040. Accessed 25/5/2019.

Education Counts (2014). Exchange rate analysis (pp.18-20). https://www.educationcounts.govt.nz/ data/assets/ pdf file/0017/115028/Exchange-rate-analysis,-June-2014.pdf. Accessed 23/5/2019.

Education Counts (2018). https://www.educationcounts.govt.nz/statistics/schooling/student-numbers/subject-enrolment. Accessed 22/5/2019.

Education Counts. Pasifika Education Plan Monitoring Report (2013-2017), NZ Government. https:// www.educationcounts.govt.nz/topics/pasifika education/pasifika-education-plan-monitoring-report. Accessed 5/5/2019.

ERO (2019). Current Provision of Pacific Bilingual Education. https://www.ero.govt.nz/assets/Uploads/Current-Provisionof-Pacific-Bilingual-Education.pdf. Accessed 4/3/2020.

European Commission. Migrants in European Schools: learning and maintaining languages (2016-2017). https:// op.europa.eu/en/publication-detail/-/publication/c0683c22-25a8-11e8-ac73-01aa75ed71a1. Accessed 20/5/2019.

European Commission (19/3/2018). New report underlines the key role of education in the inclusion of immigrant students. https://europa.eu/rapid/press-release IP-18-2021 en.html. Accessed 20/5/2019

France Actuelle (radio debate, 12/9/2018). Enseignement de l'arabe à l'école : ce qui est réellement proposé et ce qui existe déjà, Guest speaker Minister of Education, Blanquer, J. https://www.rtl.fr/actu/debats-societe/enseignement-de-larabe-a-l-ecole-ce-qui-est-reellement-propose-et-ce-qui-existe-deja-7794755314

France Immigration Statistics, Macro Trends. https://www.macrotrends.net/countries/FRA/france/immigration-statistics. Accessed 25/2/2020 
Forsdick, C. (2007). Global France, Global French: beyond the monolingual, https://online.liverpooluniversitypress.co.uk/ doi/pdf/10.3828/cfc.2017.2 Accessed 10/3/2020.

Gleeson M. and Tait C. (2010). Interaction for Learning in Teaching ELLS: an International Perspective. Fall 2010, Texas Women's University, https://twu-ir.tdl.org/bitstream/handle/11274/300/2010Gleeson172p191.pdf?sequence=7

Hill, R. (2010). Teaching Te Reo Māori as a Second Language in Primary Schools: Two Case Studies, Waikato Journal of Education, 15(3), 2010, 35-51

Hornberger, N. H. (1998). Language Policy, Language Education, Language Rights: Indigenous, Immigrant, and International Perspectives. Language in Society, 27 (4), 439-458

Immigration NZ https://www.immigration.govt.nz/new-zealand-visas/apply-for-a-visa/about-visa/pacific-access-categoryresident-visa Accessed 19/5/2019.

Insee Références - Édition 2012. Immigrés et descendants d'immigrés en France (p.151). https://www.insee.fr/frl statistiques/2861345\#tableau-Donnes. Accessed 8/5/2019.

INSEE, (Jan 2018). Chiffres clés, statistiques de la culture. Insee Première, No.1683, janvier 2018.

Jakonen-Kilpi, E. (2012). Does Finnish Educational Equality Extend to Children of Immigrants? Nordic Journal of Migration Research, 2(2) 2012:167-181

Johnstone, J., Morgan, P., Warren, S. (Aug 2018), Strategy for Languages in Education in Aotearoa New Zealand 2019 2033, Auckland Languages Strategy Working Group. https://ilep.ac.nz/sites/ilep.ac.nz/files/2018-09/Strategy\%20for \%20languages\%20in\%20educationin\%20Aotearoa\%20NZ.pdf. Accessed 20/4/2019.

Kepa, M. and Manu'atu, L. (2006). Indigenous Māori and Tongan Perspectives on the Role of Tongan Language and Culture in the Community and in the University in Aotearoa - New Zealand, The American Indian Quarterly, 30 (1/2), 2006,11-27.

Lüdi, G., (Nov 2019). 'Développement et représentations de répertoires plurilingues', presentation at INALCO symposium Le bi-plurilinguisme dans l'éducation, Paris. Attended 22/11/2019.

May, S. (2002). Accommodating Multiculturalism and Biculturalism in Aotearoa New Zealand: Implications for Language Education. Waikato Journal of Education 8:2002.

May, S. (2005). Bilingual/Immersion Education in Aotearoa/New Zealand: Setting the Context. International Journal of Bilingual Education and Bilingualism, 8:5, pp. 365-376

May, S. (2009). Pasifika Languages Strategy: Key issues. Position paper presented to NZ Parliament: https:// www.parliament.nz/resource/0000197354

Middleton, S. (1992). Equity, Equality, and Biculturalism in the Restructuring of New Zealand Schools: A Life-History Approach. Harvard Educational Review, September 1992, Vol. 62, No. 3, pp. 301-323.

Ministère de l'Éducation Nationale, "Organisation de la scolarité des élèves allophones nouvellement arrivés”, circulaire $n^{\circ}$ 2012-141 du 2-10-2012. https://www.education.gouv.fr/pid25535/bulletin_officiel.html?cid_bo=61536. Accessed 5/9/2019.

Ministère de l'Éducation Nationale, Circulaire no 86-120 sur l'accueil à l'école et circulaire no 86-119 sur l'apprentissage du français. https://www.education.gouv.fr/cid92085/la-scolarisation-des-eleves-allophones-nouvellement-arrives-et-desenfants-issus-de-familles-itinerantes-et-de-voyageurs.html\&xtmc=elevesallophones\&xtnp=1\&xtcr=3. Accessed 3/9/2019.

Ministry of Education NZ, The National Education Goals. https://www.education.govt.nz/our-work/legislation/negs/. Accessed 2/5/2019.

Ministry of Education NZ, International Education Strategy 2018-2030. NZ Government. https://enz.govt.nz/assets/ Uploads/International-Education-Strategy-2018-2030.pdf. Accessed 2/5/2019.

Ministry for Pacific Peoples (2018). Pacific Languages Framework (draft August 2018) . https://www.parliament.nz/ resource/en-nz/50SCES ADV 00DBSCH INQ $11371 \quad 1$ A270337/2c3dd45a9021e7704a7ab14645aadd2f9c2d783d Accessed 5/5/2019.

New Zealand Census, 2018. https://www.stats.govt.nz/news/new-zealands-population-reflects-growing-diversity Accessed 24/2/2020. 
New Zealand Ministry of Education, Secondary Languages by School 1998-2018 https://www.nzqa.govt.nz/ncea/ subjects/languages/. Accessed 20/3/2019.

OECD International Migration Database, https://stats.oecd.org/Index.aspx?DataSetCode=MIG. Accessed 26/2/2020.

OECD report, Helping immigrant students to succeed at school - and beyond (2015). https://www.oecd.org/education/ Helping-immigrant-students-to-succeed-at-school-and-beyond.pdf. Accessed 9/5/2019

OECD (2018), The Resilience of Students with an Immigrant Background: Factors that Shape Well-Being. https:// read.oecd-ilibrary.org/education/the-resilience-of-students-with-an-immigrant-background 9789264292093-en\#page2. Accessed 25/02/2020

OECD, PISA data on students with an immigrant background 2018. http://www.oecd.org/education/school/1APiacentini.pdf. Accessed 25/02/2020

Paulston, C. (1993). Language regenesis: A conceptual overview of language revival, revitalisation and reversal. Journal of Multilingual and Multicultural Development 14, 275-286.

RERS (2012). Repères et références statistiques sur les enseignements, la formation et la recherche, chapter 3.5, p.86

Richards, H., Conway, C., Roskvist, A. and Harvey, S. (undated AUT publication), Foreign language teachers' language proficiency and their language teaching practice. http://openrepository.aut.ac.nz/bitstream/handle/10292/10353/LLJ \%20Richards\%20Conway\%20et\%20al\%20Post\%20Print.pdf?sequence=7\&isAllowed=y

Rigoni I. (2019). 'The myth of a migration crisis in France. Transformations of public actions and solidarist actions'. In Menjivar, C., Ruiz, M., \& Ness, I. (Eds.), The Oxford Handbook of Migration Crises, New York, Oxford University Press

Rigoni, I., 'Les facettes de l'inclusion au prisme de l'hétérogénéité des EANA', in presentation at Université Bordeaux, ADEB journée d'étude. Attended 20/11/2019.

Schnapper, D., (2007). Qu'est ce que l'intégration? Éditions Gallimard, France

Shameem, N. (2003), 'Community Language Teacher Education Needs in New Zealand'. In Barnard \& Glynn (Eds.), Bilingual Children's Language and Literacy Development. Multilingual Matters Ltd., UK.

Sinkkonen, H-M \& Kyttälä, M. (2014). Experiences of Finnish teachers working with immigrant students, European Journal of Special Needs Education, 29:2, 167-183

Skutnabb-Kangas, T. (2003). 'Linguistic Diversity Biodiversity: the Threat from Killer Languages'. In Mair C. (Ed.), The Politics of English as a World Language: New Horizons in Postcolonial Cultural Studies, (pp.33-49). ASNEL Papers 7, New York

Smythe, J. (2018). Place and Status: Lessons for Refugee Interpreting Service Provision drawn from Te Reo Māori and New Zealand Sign Language Activism, [unpublished thesis for Master of Developmental Studies]. Victoria University of Wellington

Stanford Encyclopaedia of Philosophy, https://plato.stanford.edu/entries/equal-ed-opportunity/

Stewart, I., Diversity underpins school's Maori and Pasifika achievement, 9/6/2017, Radio NZ, https://www.radionz.co.nz/ international/pacific-news/332638/diversity-underpins-school-s-maori-and-pasifika-achievement. Accessed 15/5/2019.

Tuafuti, P. and McCaffery J. (2005). Family and Community Empowerment through Bilingual Education, International Journal of Bilingual Education and Bilingualism, 8, 480-503.

University of Auckland, Mandarin Language Assistant Programme. https://ci.ac.nz/chinese-in-schools/mla. Accessed $17 / 5 / 2019$.

Ward, C. and Liu, J. (2011). 'Ethno-Cultural Conflict in Aotearoa/New Zealand: Balancing Indigenous Rights and Multicultural Responsibilities'. In Landis \& Albert (Eds) Handbook of Ethnic Conflict, (pp 45-69). Springer.

Zarate, G., Lévy, D., Kramsch, C. (2008). Précis du plurilinguisme et du pluriculturalisme. Éditions des archives contemporaines, Paris 